\title{
The Effect of Low Salinity on Teredinids
}

\author{
Cristine C. Barreto*, Andrea O. R. Junqueira and Sérgio Henrique G. da Silva \\ Universidade Federal do Rio de Janeiro, Departamento de Zoologia - Cidade Universitária, Ilha do Fundão CCS \\ Bloco A, RJ - Brazil
}

\begin{abstract}
Teredinids survival in low salinities was determined in aquaria. Panels previously immersed in Ponta de Leste, Ilha Grande Bay, Rio de Janeiro, were transferred to aquaria with salinities ranging from 5.0 to 15.0 Practical Salinity Unities (PSU). The waters of Ilha Grande Bay receive a large amount of wood from the marginal rainforest vegetation, being suitable for the development of teredinids. The coastal areas of the bay are subjected to wide salinity fluctuations due to strong and sudden tropical storms. Eleven different species of teredinids were found in the panels. The critical salinity concentration for the survival of the two most common species was 11.93 PSU for Lyrodus floridanus and 12.90 PSU for Teredo furcifera. The effect of time on the mortality of teredinids at low salinities is also discussed.
\end{abstract}

Key words: Aquaria, critical salinity, teredinidae, Rio de Janeiro, wood-borers

\section{INTRODUCTION}

Wood-boring bivalves of the family Teredinidae have a key role in some coastal systems particularly for their importance in the degradation of wood and nutrient turnover. After settlement on wooden substrata, planktonic larvae metamorphose into xylophagous adults which feed on the structure they bore. Nitrogen content in their diet is complemented by planktonic filtering. A great difficulty faced by man is the protection of his property against the wood-borers without disturbing the normal functions of these organisms. The limited success obtained in controlling the activity of these mollusks has been suggested to be result of the much greater attention given to protection methods than to the study of the organisms themselves (Turner, 1971). Probably, less than $10 \%$ of teredinid species are known biologically and few have been studied in all phases of their life cycles (Turner, 1981). There is a current need for a better understanding of the biological basis of the physiology and behaviour of teredinids in order to interpret the effects of toxic agents or to determine the most effective control methods.

Studies carried out on the Pacific (Saraswathy, 1974) and Atlantic (Culliney, 1970) coasts of North America and western Africa (Hoestland \& Brasselet, 1968) show that salinity is one of the main factors affecting teredinids distribution in estuaries. The ambient salinity at any one point of an estuary can vary on a daily and/or seasonal basis, this variability increasing the stress adults, juveniles and larvae are subjected to and thus affecting their realized distribution (Attrill \& Thomas, 1996). Larvae raised in low salinity seawater exhibit slowed growth rates, increased mortality, and a possible delay of metamorphosis (Richmond \& Woodin, 1996). Turner (1966) reported that the optimum salinity and the range of salinity tolerance varies widely according to teredinid species. Salinity may affect structural and functional properties of marine organisms and, thus, modify the species composition of the ecosystem (Kinne, 1964).

Some marine environments, superimposed upon regular patterns of change in physical parameters, are subjected to stochastic events such as storms, which may cause rapid, sometimes dramatic changes in salinity concentrations (Richmond \& Woodin, 1996). Ilha Grande Bay is located on the southern coast of Rio de Janeiro, and has two connections with the sea: one, to the east, $10 \mathrm{Km}$ wide, and another to the west, $18 \mathrm{Km}$ wide (Figure 1). Its waters receive a large amount of wood from the marginal rainforest vegetation, making the bay a favorable environment for the development of teredinids (Barreto et al., 1993). The high peaks of the mountains act as a barrier for the dissipation of a humid air layer formed over the seawater surface and precipitation events are frequent. Although influenced by ocean salinity, coastal areas of the bay are hence subjected to wide salinity fluctuations as strong and sudden tropical storms occur.

\footnotetext{
* Author for correspondence
} 


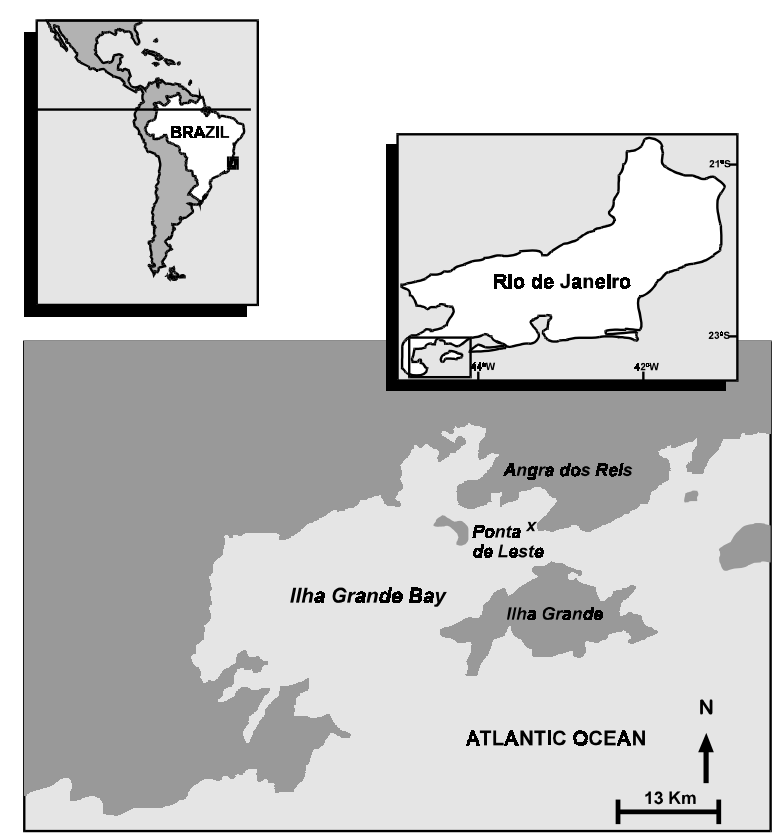

Figure 1. Ilha Grande Bay and collection site, at Ponta de Leste

Hoagland \& Turner (1981) believe that it is possible to find 9 sympatric species of teredinids in tropical waters. Experiments previously developed in the same geographic region of the present study (Martins-Silva et. al., 1988; Silva et. al., 1989; Omena et. al., 1990; Junqueira et. al., 1991) revealed the occurrence of up to $11 \mathrm{spp}$. Nevertheless, the most conspicuous species of the area (Lyrodus floridanus (Bartsch, 1922), Bankia gouldi (Bartsch) 1908 and Teredo furcifera von Martens, 1894) are not endemic and have a broad worldwide distribution.

Unlike most experiments in aquaria for studying the behaviour of other organisms, the evaluation of the teredinid survival under laboratory controlled conditions involves some methodological difficulties. The only study on this subject available in the literature was performed by Rayner (1979). Mortality rates or growth may be determined only after removing the individuals from the wood, making impossible their survival after being manipulated. Also, the study of teredinids in tropical waters is particularly difficult because of the greater species richness when compared to temperate areas. The use of X-ray techniques for observing teredinids behaviour inside wooden panels provides precise results only for the few species found in temperate areas.

The main purpose of the present study is to examine the survival of adult teredinids from Ilha Grande Bay in low salinities under controlled laboratory conditions. The collection site was located in Ponta de Leste (230 02' 03" S and 440 14' 09" W), a coastal area with little riverine input (Figure 1).

\section{MATERIALS AND METHODS}

\section{Placement of panels at the field site}

Panels were made of thin sheets of pine (Araucaria angustifolia (Bertol) O. Kuntze) each $10.0 \times 10.0 \times 0.08 \mathrm{~cm}$, compressed between 2 ceramic plates and 2 wooden plates (Junqueira et al., 1991). In a preliminary experiment, 48 panels were fixed $10 \mathrm{~cm}$ apart to a triangular PVC structure at a depth of 3 meters for a 3-monthimmersion period. This experiment was started in July 1986.

A second, low salinity experiment was started in July of 1987 when 56 new panels were immersed at the same site and depth for 3 months.

\section{Evaluation of survival in field panels}

Immediately after removal from water, following the three-month-immersion period, in each experiment, 8 blank (field) panels were analysed to evaluate the natural mortality of teredinids. Panels were analysed under a stereoscopic microscope, and teredinids counted and considered dead or alive according to their color and conservation. Dead individuals were either whitish or in an advanced process of decomposition. Identification was made up to the species level. 
Table 1. Average values and coeficient of variation (C.V.) of dead individuals found in the panels removed from the different salinity (Sal.) aquaria with time and average mortality $(\bar{x})$ and respective C.V. of field panels (preliminary experiment).

\begin{tabular}{cccccc}
\hline Sal. (PSU) & $1^{\text {st }}$ week $(\%)$ & $2^{\text {nd }}$ week $(\%)$ & $3^{\text {rd }}$ week $(\%)$ & $4^{\text {th }}$ week $(\%)$ & C.V. $(\%)$ \\
\hline 7.0 & 94.4 & 97.8 & 98.9 & 99.0 & 2.2 \\
14.0 & 9.0 & 15.2 & 32.7 & 22.4 & 33.7 \\
21.0 & 10.0 & 16.0 & 19.8 & 13.4 & 28.0 \\
28.0 & 15.0 & 12.8 & 11.6 & 10.8 & 14.6 \\
35.0 & 9.4 & 7.3 & 15.0 & 10.2 & 31.1 \\
\hline Field & \multicolumn{7}{c}{$\bar{x}=0.0 \%$} & C.V. $=0.0 \%$ \\
\hline
\end{tabular}

\section{Evaluation of survival in the aquarium- immersed panels}

The remaining 40 panels from the preliminary experiment, after the analysis of the blank panels, were evenly distributed among 5 aquaria of different salinity concentrations $(7.0,14,0,21.0$, 28.0 and 35.0 Practical Salinity Unities - PSU) to determine the critical salinity interval for the survival of the teredinids under controlled laboratory conditions. The different salinity concentrations were adjusted through the dilution of seawater (35.0 PSU) with distilled water until the desired concentration was reached according to the volume of water in the aquarium.

Salinity of the aquaria was measured every two days with a thermosalinometer and adjusted whenever necessary. Aquaria with stagnant well aerated water were used due to the difficulty of mantaining a flowing water system with different salinities.

The analysis of the panels started one week after immersion in the aquaria and lasted 4 weeks. Every week, 2 different panels were removed from each aquarium (total number $=10$ per week) and teredinids were immediately counted, identified and mortality values recorded. Panels were never reimmersed because survival of teredinids is impossible after the panels were dismounted and individuals manipulated. Thus, results from each week were obtained from different panels.

For the low salinity experiment, the 48 remaining panels were distributed among 6 aquaria of salinities 5.0, 7.0, 9.0, 11.0, 13.0 and 15.0 PSU. This interval was based on the preliminary experiment result. The analysis of the panels started one week after immersion in the aquaria. Analysis of the panels was done as in the preliminary experiment and a total of 12 panels were analysed weekly.
Data obtained from both experiments were normalized through an arcsine $\sqrt{x}$ transformation for statistical treatment (Zar, 1984).

\section{RESULTS AND DISCUSSION}

\section{Survival of Teredinids in Field and Aquarium- immersed Panels}

\section{Preliminary Experiment}

All individuals removed from the field panels were alive (Table 1). In the 40 aquarium-immersed panels from the preliminary experiment, 2095 teredinids were found (average of 52.4 individuals per panel). Previous studies in the same area all revealed a heavy borer attack after a 3-monthimmersion period. The borer population density is greater in areas such as Ponta de Leste, where wood supply is plentiful because of the surrounding vegetation mainly rainforest and mangroves (Barreto et al., 1993). The slow colonization by fouling organisms, which commonly inhibit the activity of wood-borers, can be related to the oligotrophic conditions of the site (Silva et al., 1989). Poor nutrient conditions in the water are irrelevant for teredinids that depend on the terrestrial production for their survival.

Investigation of the critical salinity interval for the survival of teredinids revealed that after one week, more than $90 \%$ of the individuals in the panels removed from the 7.0 PSU aquarium were dead; the only specimens found alive belonged to the species Bankia fimbriatula Moll \& Roch, 1931. Mortality in the 14.0 PSU aquarium was always less than 35\% (Table 1). Thus, this interval was considered critical. There was no significant difference in mortality values at salinities of 21.0, 28.0 and 35.0 PSU (TWO-WAY ANOVA, 
$\mathrm{F}=2.53, \mathrm{p}<0.01)$. Mortality values may decrease with time because, as mentioned before, two panels per aquaria were analysed weekly and not reimmersed. Thus, a variation in the resistance of the individuals inside the panels is expected.

Table 2. Percentage values of dead individuals of Lyrodus floridanus (Lf) and Teredo furcifera (Tf) removed from the different salinity (Sal.) aquaria in the preliminary experiment.

\begin{tabular}{ccccc}
\hline $\begin{array}{c}\text { Sal. } \\
(\mathrm{PSU})\end{array}$ & $\begin{array}{c}1^{\text {st }} \text { week } \\
(\mathrm{Lf} / \mathrm{Tf})\end{array}$ & $\begin{array}{c}2^{\text {nd }} \text { week } \\
(\mathrm{Lf} / \mathrm{Tf})\end{array}$ & $\begin{array}{c}3^{\text {rd }} \text { week } \\
(\mathrm{Lf} / \mathrm{Tf})\end{array}$ & $\begin{array}{c}4^{\text {th }} \text { week } \\
(\mathrm{Lf} / \mathrm{Tf})\end{array}$ \\
\hline 5.0 & $9.39 /---$ & $100.0 / 100.0$ & $100.0 /---$ & $100.0 / 100.0$ \\
7.0 & $21.6 / 0.0$ & $13.5 / 25.0$ & $34.9 / 0.0$ & $23.0 / 12.5$ \\
9.0 & $8.9 / 0.0$ & $17.1 / 12.5$ & $11.9 / 0.0$ & $13.9 / 10.0$ \\
11.0 & $8.2 / 0.0$ & $10.3 / 0.0$ & $7.4 /--$ & $8.5 /--$ \\
13.0 & $3.5 / 0.0$ & $7.0 /--$ & $14.3 / 0.0$ & $7.0 /---$ \\
\hline
\end{tabular}

Survival of the dominant species, Lyrodus floridanus appeared to be low in low salinities and a high mortality $(94 \%)$ in the 7.0 PSU aquarium was recorded from the first week. The same occurred with the second dominant species, Teredo furcifera (100\%) (Table 2). Mortality values at higher salinities were progressively smaller for both species.

\section{Low salinity experiment}

In contrast to results of the preliminary experiment, only 4 of the 8 blank panels had $100 \%$ of living individuals. The average mortality among blank panels was $5.9 \%$ (coefficient of variation $=115.0 \%$ ) (Table 3 ). Hence, this average value was compared to the mortality recorded each week in the 13.0 PSU aquarium. Significant differences were noticed from the first week $(t=1.71, p<0.05)$. Only the results referring to the 13.0 PSU aquarium were used for the $t$ test (Zar, 1984) because mortality at other salinities was much higher than those recorded for the blank panels (Table 3 ).

In the 40 aquarium-immersed panels analysed during the 4 week low salinity experiment, 1576 teredinids were found (average of 39.5 individuals per panel). Figure 2 represents the dominance of the different species in the panels (results from the 15 PSU aquarium were discarded due to the presence of fungi covering the panels from the first week). Both aquaria and blank panels showed the same dominance. The dominant species was Lyrodus floridanus (70 to $80 \%)$; followed by Teredo furcifera (15\%). Other species present in the panels were: Nototeredo knoxi (Bartsch) 1917; Bankia gouldi; Bankia destructa Clench \& Turner, 1946; Bankia carinata (Gray) 1827; Bankia fimbriatula ; Lyrodus massa (Lamy) 1923; Teredo navalis Linnaeus, 1758, Bankia campanellata Moll \& Roch, 1931 and Teredo bartschi Clapp, 1923. Excepting Teredo bartschi, all other species occurred in the panels analysed during the preliminary experiment.

Table 3. Average values and coeficient of variation (C.V.) of dead individuals found in the panels removed from the different salinity (Sal.) aquaria with time and average mortality $(\bar{x})$ and respective C.V. of field panels (low salinity experiment).

\begin{tabular}{cccccc}
\hline Sal. (PSU) & $1^{\text {st }}$ week $(\%)$ & $2^{\text {nd }}$ week $(\%)$ & $3^{\text {rd }}$ week $(\%)$ & $4^{\text {th }}$ week $(\%)$ & C.V. $(\%)$ \\
\hline 5.0 & 100.0 & 97.8 & 100.0 & 100.0 & 1.0 \\
7.0 & 97.5 & 100.0 & 100.0 & 99.2 & 1.0 \\
9.0 & 78.5 & 96.4 & 91.4 & 87.5 & 9.0 \\
11.0 & 44.6 & 85.7 & 74.6 & 80.8 & 26.0 \\
13.0 & 14.8 & 14.0 & 28.6 & 45.1 & 57.0 \\
\hline \multicolumn{7}{c}{$\bar{x}=5.9 \%$} & C.V. $=115.0 \%$ \\
\hline
\end{tabular}




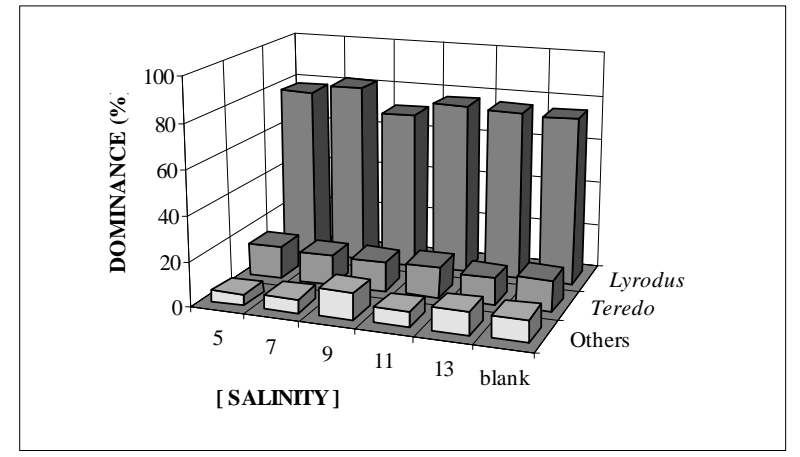

Figure 2. Dominance values of Lyrodus floridanus, Teredo furcifera and other species recorded in the panels removed from the aquaria and in the field panels ( $\mathrm{n}=48$ replicates; $\mathrm{N}=1797$ individuals).

Mortality values decreased from lower to higher salinities and the coefficient of variation increased (Table 3). These results may be best explained on the basis of decreasing teredinid physical protection from the surrounding environment with decreasing salinity. Turner (1971) stated that the sealing of the burrow entrance with their pallets provided an effective deterrent to osmotic stress. This probably happened, but under limited circumstances, in both experiments. In extremely adverse conditions (low salinity), this mechanism is not very efficient, and the effects of external medium are drastic and immediate. However, in aquaria of higher salinity (higher coefficient of variation recorded for the low salinity experiment), teredinids are able to resist for a longer period of time, thus causing a variation in the mortality values. The pallet's mechanism may not last long because even the 13 PSU aquaria represents a low salinity concentration at which teredinids will eventually die. Under natural conditions, however, the restricting factor is not salinity, but the wood supply which will eventually cause the teredinids death whenever it becomes limited. The survival of the individuals in this case is not related to salinity and the effect of the pallets is more successful.

In the lower salinity aquaria (5.0 and 7.0 PSU), mortality was very high. In the 5.0 PSU aquarium, only a single Bankia fimbriatula was found alive in a panel analysed in the second week. Also, this was the only species found alive in the 7.0 PSU aquarium throughout the preliminary experiment. Despite the small number of individuals of Bankia fimbriatula in the panels (three, during all the low salinity experiment), data from other studies (Serpa, 1978; Junqueira \& Silva, 1991) indicated that this is an eurihaline species, withstanding salinities as low as 0.0 PSU. High mortality values were still recorded in the panels immersed in the 9.0 PSU aquarium (78.5 to 100\%). Mortality became progressively less at the higher salinities tested. The percentage of dead individuals in the 11.0 PSU aquarium was 44.6 to 85.7 , while in the 13.0 PSU aquarium lower values were reached (14.0 to $45.1 \%$ ) (Table 3 ).

\section{Survival of Lyrodus in the Aquarium-immersed Panels}

The two-way analysis of variance based on data from Table 4 shows that the different salinities $(F=42.89, p<0.05)$ have a greater influence on the mortality of Lyrodus floridanus than time of immersion $(\mathrm{F}=3.28, \mathrm{p}<0.05)$. However, Figure 3 shows a distinct increase in mortality with time in the 13.0 PSU aquarium from the second week on.

Table 4. Percentage values of dead individuals of Lyrodus floridanus (Lf) and Teredo furcifera (Tf) removed from the different salinity (Sal.) aquaria in the low salinity experiment.

\begin{tabular}{ccccc}
\hline $\begin{array}{c}\text { Sal. } \\
(\mathrm{PSU})\end{array}$ & $\begin{array}{c}1^{\text {st }} \text { week } \\
(\mathrm{Lf} / \mathrm{Tf})\end{array}$ & $\begin{array}{c}2^{\text {nd }} \text { week } \\
(\mathrm{Lf} / \mathrm{Tf})\end{array}$ & $\begin{array}{c}3^{\text {rd }} \text { week } \\
(\mathrm{Lf} / \mathrm{Tf})\end{array}$ & $\begin{array}{c}4^{\text {th }} \text { week } \\
(\mathrm{Lf} / \mathrm{Tf})\end{array}$ \\
\hline 5.0 & $100.0 / 100.0$ & $100.0 / 100.0$ & $100.0 / 100.0$ & $100.0 / 100.0$ \\
7.0 & $99.0 / 100.0$ & $100.0 / 100.0$ & $100.0 / 100.0$ & $100.0 / 100.0$ \\
9.0 & $70.2 / 100.0$ & $100.0 / 100.0$ & $84.6 / 100.0$ & $93.4 / 100.0$ \\
11.0 & $43.7 / 62.5$ & $84.1 / 100.0$ & $71.1 / 100.0$ & $84.0 / 71.5$ \\
13.0 & $13.3 / 16.7$ & $13.2 / 8.3$ & $28.0 / 0.0$ & $41.5 / 80.0$ \\
\hline
\end{tabular}




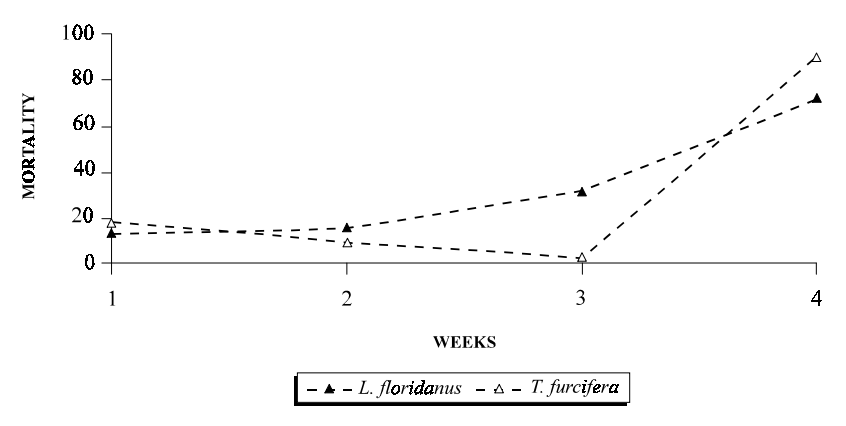

Figure 3. Mortality values of Lyrodus floridanus and Teredo furcifera at weekly intervals over a period of four weeks in the 13 PSU aquarium-immersed panels, low salinity experiment.

The Tukey test (Zar, 1984) grouped 5.0 and 7.0 PSU aquaria, where high mortality values were recorded. The 13.0 PSU aquarium was separated from the others as a consequence of lower mortality. This was the only salinity where the number of dead individuals was always less than the number of living ones. The 9.0 and 11.0 PSU aquaria still presented marked differences, especially in the first week, when mortality values were more in contrast to those from the other aquaria (Table 4), and were then, gathered in a third group.

Linear regressions based on Table 4 correlated the mortality of Lyrodus floridanus with the different salinities for each week analysed (Zar, 1984). No significant difference between intercept and slope values of the curves was found $(\mathrm{p}<0.05)$. Hence, it was possible to determine one curve referring to the 4 weeks (Figure 4). This curve showed that $50 \%$ of mortality $\left(\mathrm{L}_{\mathrm{c}} 50\right)$ occurred in $11.93 \mathrm{PSU}$ $( \pm 2.0 \mathrm{~S}, \mathrm{p}<0.05)$.

\section{Survival of Teredo in the Aquarium-immersed Panels}

Teredo furcifera showed slightly less tolerance to low salinity than Lyrodus floridanus, $100 \%$ mortality occurred in 5.0, 7.0 and 9.0 PSU aquaria. Mortality was always above $60 \%$ in 11.0 PSU aquarium. In the fourth week, mortality reached $80 \%$ in the 13.0 PSU aquarium, although in the other weeks this value was never greater than $17 \%$ (Table 4).
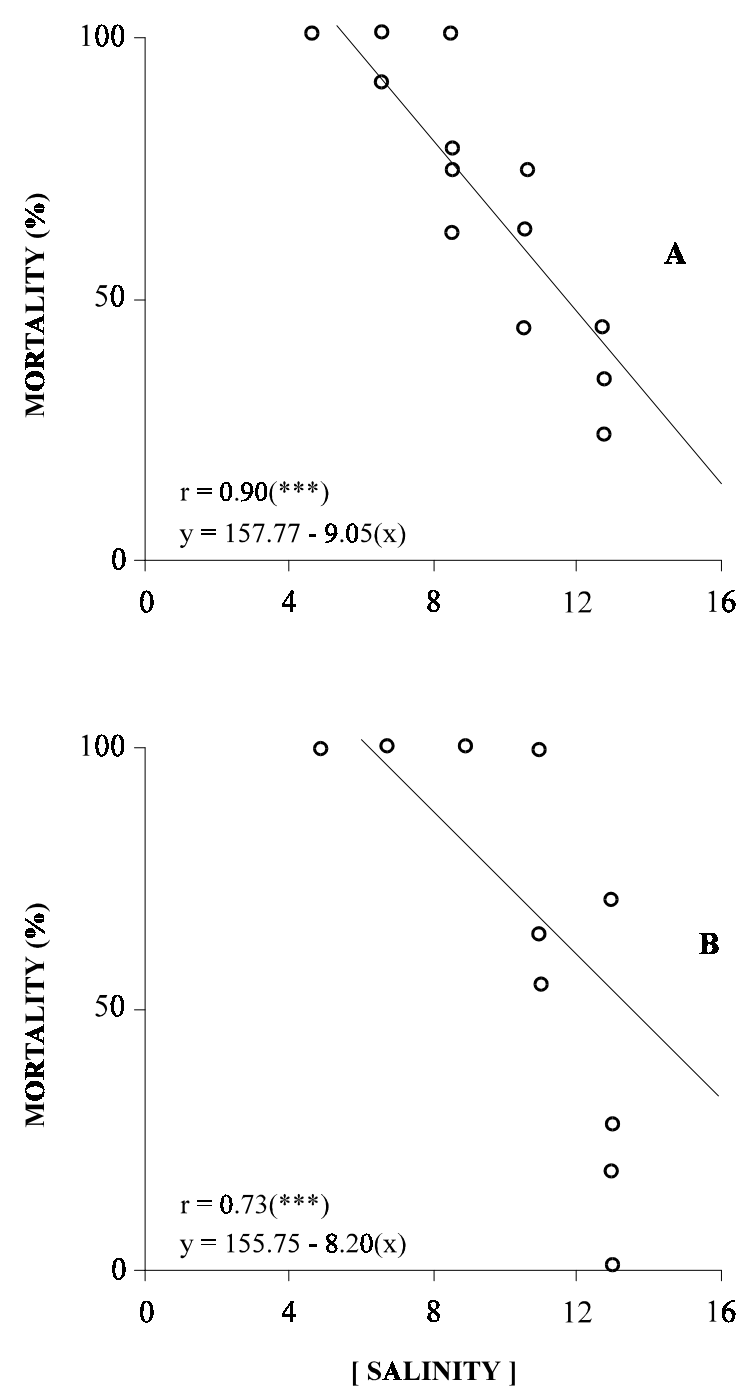

Figure 4. Linear regressions (mortality vs. salinity) of the species Lyrodus floridanus (A) and Teredo furcifera (B); $\mathrm{n}=20$, for both cases.

In contrast to Lyrodus floridanus, no gradual increase in mortality with time was observed for T.furcifera (Figure 3). The two-way ANOVA result also showed that salinity $(\mathrm{F}=11.58, \mathrm{p}<0.05)$ has a greater influence on mortality of the species than time of immersion $(\mathrm{F}=0.29, \mathrm{p}<0.05)$. The Tukey test for T. furcifera based on the ANOVA result grouped the aquaria differently. The 5.0, 7.0 and 9.0 PSU aquaria were grouped and 11.0 and 13.0 PSU aquaria formed the second and third group, respectively.

Regression (Figure 4) of the 4 week data $(\mathrm{p}<0.05)$ showed that $50 \%$ mortality of Teredo furcifera occurred in 12.9 PSU ( \pm 2.0 PSU). Although this value overlaps with the one obtained for $L$. floridanus $(11.93 \pm 2.0 \mathrm{PSU})$, results from the Tukey test suggests that L. floridanus is a little 
more tolerant to low salinity than $T$. furcifera. The 5,0 and 7,0 PSU aquaria were grouped when data from $L$. floridanus were considered. Nevertheless, results refferring to $T$. furcifera show that the 5,0; 7,0 and 9,0 PSU aquaria are part of a same group due to a $100 \%$ mortality of the species recorded along the 4 weeks (Table 4).

A number of studies carried out in estuarine environments have long been positively relating wood-boring activity with increased salinity (Trussel et al., 1956; Kristensen, 1969 and Culliney, 1970). Quayle (1959) suggested that reduced salinity reduces growth by halting or slowing boring and feeding.

Available data also show poor survival of $L$. floridanus and $T$. furcifera in reduced salinities. Nair (1975), in an experiment performed on the west coast of India, recorded the settlement of $T$. furcifera only before the monsoon, when water salinity was between 28.0 and 35.0 PSU. During and after this period (salinity between 1.5 and 23.0 PSU) no recruitment was recorded.

L. floridanus was dominant among 9 species of wood-boring mollusks in Ilha Grande Bay (Silva et al., 1989), where salinity is never below 20.0 PSU.

Junqueira \& Silva (1991) recorded a progressive decrease in the number of individuals per panel in stations located closer to the mouth of Tijuca Lagoon, Rio de Janeiro, due to lower salinities. A tolerance range was suggested for L. floridanus between 17.0 and 35.0 PSU, according to its presence in the different stations. L. floridanus and T. furcifera were not found in the inner part of the lagoon (average salinity below 20.0 PSU).

Rayner (1979) noticed that L. floridanus and $T$. furcifera were only abundant in areas where salinity is higher than 20.0 PSU, eventually occurring in other areas as a function of occasional salinity fluctuations. The author suggests a relation between teredinid distribution and larval tolerance range during dispersion, settlement and metamorphosis.

Results obtained by Richmond \& Woodin (1996) are consistent with several previous studies which have shown that larvae of marine invertebrates grown in reduced salinity levels grow at significantly slower rates. The authors mimicked salinity fluctuations soon after storm events in an estuary with little riverine input and evaluated its effects on the growth and behaviour of larvae of the marine mud snail Ilyanassa obsoleta. Larvae subjected to low salinity concentrations (5.0 - 10.0
- 15.0 PSU) showed reduced size and activity when compared to control ones. According to the authors, a delay of metamorphosis in any marine invertebrate could have several negative effects on larvae such as increasing the chance of encountering planktonic predators or a longer exposure to unfavorable storm-related conditions that could be increasingly detrimental to larval growth and survival. Also, developmental delays have the potential to be a favorable response to salinity fluctuations; by delaying settlement, larvae may in fact increase their chances of being transported to a part of the estuary where salinity pulses are less severe.

In the present study, the critical salinity concentrations for the survival of Lyrodus floridanus and Teredo furcifera (11.9 and 12.9 PSU, respectively) are lower than those obtained by other authors, for the same species, in salinity tolerance experiments. Our study focused on adults and not on the larval or colonization stages of the species. Hence, any discussion correlating the effects of reduced salinity on teredinid larvae recruitment and its consequence on adult distribution could not be acessed. The experiments above mentioned did necessarily involve the larval tolerance to the different salinities, once new panels were used for collecting the individuals. The fact that adult specimens are not found in a determined field salinity does not necessarily mean that the adults are unable to survive. Their absence (or lower density) may reflect a much smaller tolerance of the larvae when compared to the adults. This could possible explain the differences between our results and those suggested by other authors.

The more we know about the response of teredinids to - sometimes unpredictable - changes in their physical environment, the more we understand the underlying forces driving patterns of population dynamics and the control methods to protect wooden structures against borers.

\section{ACKNOLEDGEMENTS}

We are grateful to Dr. Ruth Turner, Dr. Claudio Tiago and Dr. Paulo Cesar de Paiva, who kindly reviewed the content of this paper. We also thank Dr. Fátima Cristina Bacellar for her participation during the preliminary experiment, Dr. Allen Norton Hagler for the english review and Ricardo Varotto and Asteclides Alvaro for graphic art assistance. 


\section{RESUMO}

A sobrevivência de moluscos bivalves perfurantes de madeira da família Teredinidae foi avaliada a partir de sua manutenção em aquários de baixa salinidade. Painéis de madeira previamente imersos em Ponta de Leste, Baía da Ilha Grande, $\mathrm{RJ}$, foram transferidos para aquários, contendo água do mar, cujas concentrações salinas variaram de 5,0 a 15,0 PSU. A Baía da Ilha Grande recebe uma grande quantidade de madeira da vegetação marginal de Mata Atlântica, o que torna o ambiente particularmente favorável ao desenvolvimento de teredinídeos. As áreas costeiras da baía estão sujeitas a grandes variações salinas decorrentes de tempestades tropicais que ocorrem súbita e intensamente. A salinidade crítica à sobrevivência das duas espécies mais comuns nos painéis foi de 11,93, para Lyrodus floridanus e 12,90 para Teredo furcifera. O efeito do tempo na mortalidade dos teredinídeos, quando sujeitos a baixas salinidades, foi discutido.

\section{REFERENCES}

Attrill M J, Thomas R M (1996) Long-term distribution patterns of mobile estuarine invertebrates (Ctenophora, Cnidaria, Crustacea: Decapoda) in relation to hydrological parameters. Mar. Ecol. Prog. Ser. 143: $25-36$

Barreto C C, Silva S H G, Lavrado H P (1993). Distribution of teredinids along the southeast coast of Brazil. Oebalia J. Mar. Biol. Ocean. 19: 155-162

Culliney J L (1970) Larval biology and recruitment of the shipworms Teredo navalis and Bankia gouldi in the Newport Estuary, North Carolina. Ph.D. Thesis, Dept. Zoology, Duke University, NC.

Hoagland K E, Turner R D (1981) Evolution and adaptative radiation of wood-boring bivalves (Pholadacea). Malacologia. 21 (1-2): 111-148

Hoestland H, Brasselet M P (1968) Cycle biologique de Teredinidae saumâtres d'Afrique equatoriale occidentale et influence de la salinité. $C$. $r$. hebd. Séanc Acad. Sci. Paris. 266: 623-625

Junqueira A O R, Silva S H G (1991) Estudo experimental de Teredinidae Rafinesque, 1815 (Mollusca:Bivalvia) do estuário da Lagoa da Tijuca. Rio de Janeiro, RJ, Brasil. Rev. Bras. Biol. 51 (1): 113-116

Junqueira A O R, Omena E P, Silva S H G (1991) A comparative study of the methods used to evaluate the activity of Teredinidae molluscas. J. Exp. Mar. Biol. Ecol. 150: 107-115
Kinne O (1964) The effects of temperature and salinity on marine and brackish water animals. II. Salinity and temperature combinations. Oceanogr. Mar. Biol. Ann. Ver. 2: 281-339

Kristensen I (1969) Attacks by Teredo navalis L. on inner Danish waters in relation to environmental factors. Vidensk. Medd. Dan. Naturhist. Foren, 132: 199- 210

Martins-Silva M J, Silva S H G, Junqueira A O R (1988) Distribuição vertical de Teredinidae (Mollusca:Bivalvia) em Portogallo, Angra dos Reis, Rio de Janeiro, Brasil. Rev. Bras. Zool., 5 (1): 155165

Nair N B (1975) Shipworms of Venezuela. Report on a collection from the Gulf of Cariaco. Bol. Inst. Oceanogr. Univ. Oriente Cumana, 14 (2): 129-146

Omena E P, Junqueira A O R, Silva S H G (1990) Resistência de Teredinidae Rafinesque, 1815 (Mollusca:Bivalvia) a diferentes períodos de exposição ao ar. Rev. Bras. Biol., 50 (3): 701-707

Quayle D B (1959) The early development of Bankia cetacea Tryon. in marine boring and fouling organisms. D.L. Ray. Univ.Washington Press, 12: 157-174

Rayner S M (1979) Comparison of the salinity range tolerated by Teredinids (Mollusca:Bivalvia) under controlled conditions with that observed in an estuary in Papua New Guinea. Aust. J. mar. Freshwat. Res., 30: $521-533$

Richmond C E, Woodin S A (1996) Short-term fluctuations in salinity: effects on planktonic invertebrate larvae. Mar. Ecol. Prog. Ser., 133: 167177

Saraswathy W (1974) The influence of salinity on a tropical estuarine shipworm Nausitora hedleyi Schipman (Bivalvia:Teredinidae). Hydrobiologica, 44 (4): 397-411

Serpa F G (1978) Natural resistance to marine borers of nine north and northeastern Brazilian wood species. Floresta, 9 (2): 97-102

Silva S H G, Junqueira A O R, Martins-Silvam, M J Zalmon I R, Lavrado H P (1989) Fouling and woodboring communities distribution on the coast of Rio de Janeiro, Brazil. In: Coastlines of Brazil, Neves C, O.T.Magon (eds). American society of civil engineers, New York, pp. 95-109.

Trussel P C, Greek B A, Lebrasseur R J (1956) Storage ground study (III). Pulp and paper magazine of Canada, 57 (2): 77-80

Turner R D (1966) A survey and ilustrated catalogue of the Teredinidae (Mollusca:Bivalvia). Museum of Comparative Zoology, Harvard University, Cambridge Mass. 256

Turner R D (1971) Identification of wood boring molluscs. Marine borers, fungi and fouling organisms of wood. In: Jones E B G, Eltinghan S K, Org. Econom. Coop. Develop. Paris. 17-64 
Turner R D (1981) "Wood Islands" and "Thermal vents" as centers of diverse communities in the deep sea. Biol. Morya (Vladivost.), 1: 3-10

Watson C J, McNeil F A, Johnson R A, Iredale T (1936) Destruction of timber by marine organisms in the port of Brisbane. Queensl. For. Serv. Bull. 12
Zar J H (1984) Biostatistical analysis. Prentice-Hall Inc., Englewood Cliffs, New Jersey, second edition, 718

Received: April 05, 1999 .

Revised: November 23, 1999; Accepted: June 26, 2000. 